\title{
Factors that shape the competitiveness of small innovative companies operating in international markets with a particular focus on business advice
}

\section{Edward Stawasz ${ }^{1}$ iD}

\begin{abstract}
The aim of the presented paper is to identify the significance of selected determinants of the competitiveness of small, innovative enterprises operating in international markets that use business advice. The achievement of this goal required identifying the determinants of the competitiveness of small companies (characteristics of managers, characteristics of enterprises) as well as examining the motives, areas and effects of using business advice. The issue of business knowledge absorptive capacity as a determinant of the competitiveness of small enterprises and the effectiveness of using external business knowledge was also presented. The second part of the paper presents the results of empirical research conducted using the CATI technique on a sample of 67 small, innovative Polish enterprises operating in international markets and simultaneously benefiting from business advice. The conducted research confirmed the hypothesis of a significant, moderating influence of business advice on the system of competitiveness determinants of enterprises. The hypothesis concerning a positive relationship between business advice and enterprises' capacity for absorbing business knowledge, and indirectly their competitiveness, was also confirmed. Improving the competitiveness of enterprises requires using business advice and enhancing their business knowledge absorptive capacity.

Keywords: small business, determinants of competitiveness in international markets, business advice, business knowledge absorptive capacity.
\end{abstract}

1 Edward Stawasz, Ph.D. Habilitated, Associate Professor, Head of the Department of Entrepreneurship and Industrial Policy, Faculty of Management, University of Lodz, 22/26 Matejki, 90-237 Lodz, Poland, e-mail: edward.stawasz@uni.lodz.pl (ORCID ID 0000-0003-4744-6096).

Received 8 March 2018; Revised 3 August 2018, 14 September 2018, 7 January 2019, 12 February 2019; Accepted 20 February 2019 
INTRODUCTION

The issue of determinants that shape the competitiveness of small innovative enterprises is still poorly recognized in management literature (Sipa, GorzeńMitka, \& Skibiński, 2015; Adamik, 2011; Ciszewska-Mlinaric, Mlinaric, \& Obłój, 2011). This situation seems particularly important for enterprises that are increasingly more active in international markets (Bianchi, Glavas, \& Mathews, 2017; Stoian, Rialp, Rialp, \& Jarvis, 2016). The scope and intensity of the impact are very diverse due to numerous industry-related determinants, the scale and age of enterprises, prevailing attitudes and development orientations, the level of business knowledge and business management skills, as well as the innovative and knowledge absorptive capacity, or the role of business advice (Navarro \& Eldridge, 2016; Blackburn, Hart, \& Wainwright, 2013; Stawasz, 2013; Gudkova, 2008; Wiklund \& Shepherd, 2003). There is no in-depth empirical material concerning the role of particular factors in relation to small enterprises operating in the Polish economy which is characterised by a lower level of experience of small companies compared to the EU's old countries, mainly due to the relatively short development period of the SME sector (2530 years) and the unsatisfactory state of business advice development. For this reason, it may be interesting to examine the role of management-related factors, with particular emphasis on business advice and business knowledge absorptive capacity, in the process of shaping the competitiveness of small innovative enterprises operating in international markets.

Business advice is considered as an important factor in improving management, especially in the case of small innovative entities, both in the area of reducing barriers to their development and in the field of development management. Managers rarely have all the knowledge necessary for conducting effective and successful business activity (Mole, North, \& Baldock, 2017). The necessary knowledge they are lacking can be obtained from the environment, from advisors, in the form of professional and independent services. Their aim is to help managers and enterprises achieve their goals by solving management problems as well as by assisting them in identifying and exploiting new opportunities, learning and implementing changes.

The use of business knowledge for shaping the competitiveness of small enterprises forces the company management to face challenges, the more so given that small companies usually do not have the appropriate management structure or professional managers. Business knowledge absorptive capacity, including the ability to recognize the value of new knowledge, and assimilate and transform it into a commercial outcome, plays an important role in this respect (Grabowski \& Stawasz, 2017; Zahra \& George, 2002). These are 
particularly important and difficult to obtain capabilities in technologically advanced and innovative industries (Patterson \& Ambrosini, 2015).

The paper is devoted to discussing the role of factors shaping the competitiveness of small innovative enterprises operating in international markets in the context of specific characteristics of their managers and the enterprises themselves. The moderating influence of business advice and business knowledge absorptive capacity in this process was also discussed. The hypothesis was adopted about a positive and significant impact of business knowledge and managerial skills on the competitiveness of enterprises strengthened by business advice and business knowledge absorptive capacity. The second part of the paper presents the results of empirical research conducted in 2016 with the use of the CATI technique on a sample of 67 small, innovative Polish enterprises operating in international markets. The analysis of the research results confirms the existence of a relationship between management-related factors and the competitiveness of enterprises. Using business advice and increasing the capacity for the absorption of business knowledge obtained through advisory services can broaden the scope of the determinants of enterprises' competitiveness and can be considered as an effective factor in improving competitiveness, especially in the case of enterprises characterized by an already high level of competitiveness.

\section{LITERATURE REVIEW}

\section{Factors shaping the competitiveness of small innovative enterprises}

Competitiveness is a feature of an efficiently operating enterprise which is related to the process of competition in which companies compete with one another (Adamik, 2011; Liao, Rice, Lu, \& I-Ch, 2015). Competitiveness of companies is defined as their ability to function in a competitive environment (Sipa et al., 2015; Dzikowska \& Gorynia, 2012) in which other entities operate. It is the ability to design, manufacture and sell products and services on the market where similar products and services are offered by other business entities. Thus, multidimensional competition between entities understood as access to resources in order to transform them into products and services that meet broad consumer requirements, is a feature of the market (Stankiewicz, 2002). Being competitive ensures companies' sustainable development.

In the classical approach, determinants of competitiveness are divided into external and internal ones (Carvalho \& Costa, 2014; Piatkowski, 2012). External factors result from the fact that the company is affected not only by the competitive environment (other enterprises) but also by the general, 
macroeconomic, mesoeconomic and microeconomic environment (Lisowska, 2015). Internal factors are related to the ability of enterprises to develop their own competitiveness (their own competitive advantages). The explanations in this regard are provided by the modern trends in the theory of enterprises: resource, competence and knowledge-based ones (Freiling, Gersch, \& Goeke, 2008; Plawgo, 2004), which have emerged as a response to the departure from the classic strategies of cost leadership, differentiation and focus which concentrated on the basic external factors, mainly market ones, but which did not form the basis for sustainable competitiveness of small enterprises (Zvirblis \& Buracas, 2012; Karpacz, 2011; Man, Lau, \& Snape, 2008). Internal capabilities of small entities, which are key to their competitiveness, occur at both the strategic and organizational levels (Chaston, 2010). The former include the ability of the company to achieve a special market position that gives it a cost advantage or an advantage in diversifying products as well as the ability to use it effectively. It is, therefore, the ability to identify emerging opportunities and formulate an effective strategic response. Key organizational skills include knowledge, innovation, productivity and human resources (Wach, 2017; Stanisławski, 2013).

A conceptual model illustrating the factors shaping the competitiveness of small innovative enterprises in international markets is presented in Figure 1. In line with the currently dominant resource-based approach and competence-based theories of the firm in shaping the development of enterprises and their competitiveness, a total of fourteen factors were distinguished for research purposes: the age of enterprises, the level of management, the industry in which the enterprises operate and innovations. Among the management-related factors, the following were distinguished: the number of people on the board, family relations among the management, managers' experience, managers' education profile, managers' level of business knowledge, business knowledge absorptive capacity, business development priorities, the form of planning and business advice.

The development of the business knowledge base, development orientation and improvement of the management level, as well as building knowledge absorptive capacity and its use for shaping the competitiveness of enterprises may require external support in the form of state aid or professional business advice, important especially for small innovative entities (Caiazza, Richardson, \& Audretsch, 2015; Sciascia, D’Oria, Bruni, \& Larraneta, 2014; Stawasz, 2013). 


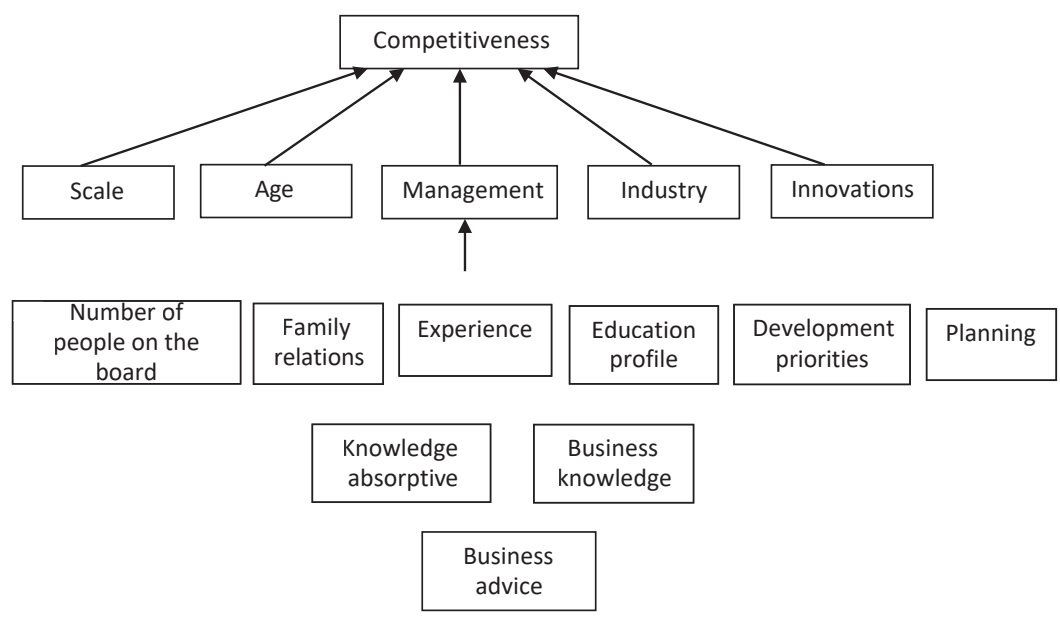

Figure 1. Factors determining the competitiveness of small enterprises - a conceptual model

The issue of the role of business advice in the management of small innovative enterprises is still poorly explored in the literature (Głodek, Łobacz, Stawasz, \& Niedzielski, 2016; Robson \& Bennett, 2000). The results of research are ambiguous. On the one hand, there are studies showing a positive impact of business advice on management and business performance (Grabowski \& Stawasz, 2017; Delanoe, 2013; Mole et al., 2017; Malinowski, 2017). On the other hand, there are also studies indicating a limited influence of business advisors on the pro-development orientation of managers and business competitiveness (Johnson et al., 2007; Bennett \& Robson, 2003). For this reason, it may be interesting to examine the impact of business advice on management, including the creation of knowledge in the field of management and shaping the competitiveness of enterprises.

\section{Business advice}

Business advice is one of the elements of external support for enterprises. Its aim is to help managers and enterprises achieve their goals by solving problems in the sphere of management, identifying and exploiting new opportunities, as well as learning and implementing changes (Yusoff, 2010; Ajmal, Nordstrom, \& Helo, 2009). It includes the transfer of information on conducting business activity, both in terms of current and strategic management (Blackburn et al. 2013), serving as a potential source of competitive advantage (Gooderham, Tobiassen, Doving, \& Nordhaug, 2004). 
Its scope covers such management areas as the organizational structure, marketing and market analysis, accounting systems, motivation and personnel policy, planning, innovations, etc. Advisory services are provided by professional consultants from the public or commercial sphere, taking on various forms, starting from providing general knowledge through specialized training to coaching and mentoring (Mole et al. 2017; Johnson, Webber, \& Thomas, 2007; Bennett \& Robson, 2003). The sources of business advice are usually accountants, suppliers, bank employees, customers or other business partners. Due to the fact that the general approach to management in small enterprises is usually informal, entrepreneurs often also use informal sources of advice that are cheap and easily available, including friends and family or other advisors in their own environment (Soriano \& Castrogiovanni, 2012; North, Baldock, Mole, Wiseman, \& Binnie, 2011).

Benefits of business advice in enterprises can be divided into 'soft' ones, resulting from business support in dealing with problem solving, formulating development strategies or improving managerial abilities, and 'hard' ones, such as obtaining economic and market results (profits, turnover, costs) or improving the competitive position (Ramsden \& Bennett, 2005). With regard to shaping competitiveness as a benefit resulting from business advice, it is possible to distinguish between a direct and indirect impact. The direct impact concerns the provision of strategic advice for improvement of innovativeness, growth and development of the company. The indirect impact, on the other hand, includes the provision of business support in the form of solutions and procedures aimed at increasing the amount of knowledge, managerial experience and practice of the enterprise and its managers useful for strategic management, as well as support for strengthening the relationship between managers' knowledge and formulating development strategies (Łobacz \& Głodek, 2015; Ramsden \& Bennett, 2005).

External advisory services seem to be necessary for small enterprises, as such services can help them overcome numerous barriers, contribute to their survival and the achievement of market success (Gooderham et al., 2004; Bennett \& Robson, 2003). This is due to the fact that they have small and limited resources, in particular knowledge and skills as well as management experience, which has a direct impact on the difficulties of solving emerging problems (Blackburn et al., 2013; Supyuenyong, Islam, \& Kulkarni, 2009). The use of external sources of business advice is generally stimulated by the gap between the internal resources of business knowledge and the resources necessary to achieve business objectives. It seems to be particularly important for innovative companies operating in international markets, especially when their competitive situation is perceived in terms of dependence on the possibility of effective access to knowledge resources 
(Piatkowski 2012; Kang \& Kang, 2009). It is indicated that the use of business advice is diversified due to the specificity of business, market, technology, sector or geographic location (Blackburn et al., 2013; Mole et al., 2017).

The attributes of small enterprises related to their size, however, may create barriers to the use of business advisory services such as: low awareness of the possibility of using advisory services, difficulties in evaluating the quality of consulting services, an unclear benefit/cost ratio and, hence, a weak interest in such services (Yusoff, 2010), difficulties with identification of problems and formulation of the demand for external advisory services, problems with choosing the right advisor, fear of losing control over the company and revealing one's own limited management competences, and problems with the limited capacity for absorption of the acquired knowledge (Chen, Chen, \& Lee, 2008). These barriers are usually much higher in small enterprises than in the case of larger enterprises and are mainly internal in nature.

Among the factors that may determine a positive relationship between the use of advisory services and the level of knowledge of enterprises along with their competitiveness, the following ones should be mentioned: factors characterizing the manager (education and age, position in the enterprise), factors related to the enterprise (scale of activity, age, industry, location, profile of activity) and factors related to development orientation (having a development strategy, knowledge gap). These factors and their interconnectedness differentiate the sector of small enterprises (Dobrea \& Maiorescu, 2015).

\section{Business knowledge absorptive capacity}

For the assessment of the importance of business advice for the competitiveness of small enterprises, the concept of knowledge absorptive capacity may be useful. In the management literature, knowledge absorptive capacity is defined as the ability of enterprises to recognize the value of new knowledge, and assimilate and transform it into a commercial outcome (Zahra \& George 2002). It is a dynamic ability, as it can influence gaining a competitive advantage in a dynamic environment by supporting, among others, the process of innovation and strategic flexibility (Matejun, 2015; Volberda, Foss, \& Lyles, 2010).

Todorova and Durisin (2007) distinguish five components of knowledge absorptive capacity, i.e.: (i) the ability to evaluate external knowledge, (ii) the ability to acquire knowledge, (iii) the ability to assimilate knowledge, (iv) the ability to transform knowledge, and ( $v$ ) the ability to exploit knowledge (see Figure 2). Distinguishing these capabilities is important for the evaluation of their unique contribution to creating innovation and competitive advantage 
of enterprises - it helps to explain why enterprises differ, why some are more effective than others in acquiring and using knowledge (Chen et al., 2008). The system of interdependencies between the various components of absorptive capacity is complicated; there is no consistency in the literature as to their order or strength of connections and their importance depending on the area of activity, dynamics of the environment or development strategy (Patterson \& Ambrosini, 2015).

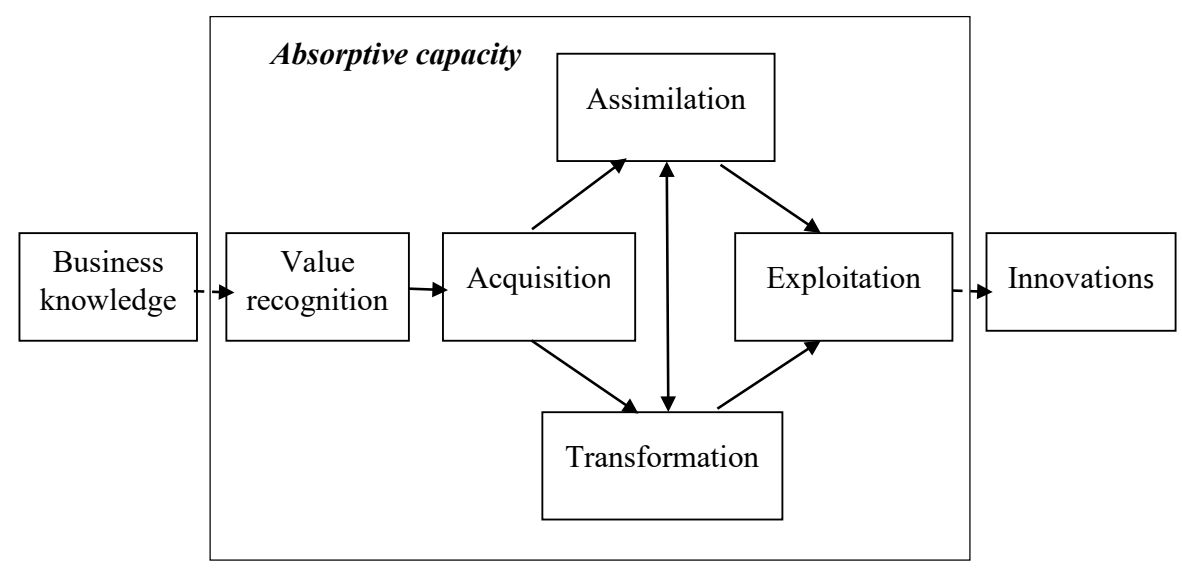

Figure 2. Business advice and business knowledge absorptive capacity Source: own elaboration based on Todorova and Durisin (2007).

The use of business knowledge by small innovative enterprises to improve their competitiveness in international markets forces them to face challenges which are made even greater by the fact that they usually do not have an appropriate management structure or professional managers (especially micro-enterprises). The ability to recognize the value of advisory information offered, as well as to assimilate, analyze, interpret and understand it, plays an important role in this respect (Navarro \& Eldridge, 2016). These are particularly important and difficult to obtain capabilities in technologically advanced and innovative industries (Patterson \& Ambrosini, 2015). The ability to transform business advice information means the capacity for changing and developing procedures that allow the integration of existing knowledge with advisory knowledge, expanding the knowledge base, modifying it, and achieving synergy. In turn, the ability to exploit this knowledge resource means the opportunity to improve existing management competences or create new ones (including competences for building development strategies or developing innovations). 


\section{RESEARCH METHODS}

The study on selected determinants of the competitiveness of small innovative enterprises operating in international markets, taking into account business advice, was conducted under the direction of the author in 2016 as part of the National Science Centre project entitled "Shaping the Competitiveness of a Small Company - the Role of Business Advice" (no. UMO-2012/07/B/HS4/03019). The aim of the research was to determine the impact of business advice on building and maintaining the competitiveness of small, innovative Polish enterprises. The survey was conducted using the technique of computer-assisted direct telephone interviews (CATI), carried out by means of a questionnaire form, with the owners or co-owners of the enterprises surveyed or their general managers. In the research methodology, it was assumed that the sample would comprise 400 Polish enterprises from the small business sector (with up to 49 employees) from various industries, randomly selected using a random number generator out of a group of 9,703 companies from the REGON CSO database, operating throughout the country, meeting the innovation criterion and using external business advisory services in the last three years before the interview.

The original data obtained as a result of surveys were subjected to statistical analysis and statistical comparative analysis. A standard data analysis and description procedure in the framework of descriptive and mathematical statistics was used in the study. The selection of factors determining the impact of business advice on selected areas of operation and performance of small innovative companies was carried out taking into account the following criteria: substantive, formal and statistical.

\section{Characteristics of the research sample}

In the market structure of the 400 surveyed enterprises, the local and national market predominated (respectively: $37.5 \%$ and $45.5 \%$ of enterprises), while there were 67 (16.8\% of the total sample) entities for which the international market was dominant. In the analyzed sample, 67 enterprises with a dominant share in the international market were mostly mature enterprises with a 4-10 year presence in the market (2/3 of the sample), while the average employment rate was 13 people, i.e., three times more compared to all the other surveyed enterprises. The industry structure of the sample was very diverse: services predominated $(75.2 \%$ of enterprises), including enterprises from the IT sector (29.1\%), followed by trade (13.4\% of enterprises) and manufacturing ( $10.4 \%$ of enterprises). 
All the surveyed enterprises were innovative, according to the criterion of novelties which the company introduced in 2013-2015, i.e., new or improved products/services, new or improved methods of production/ service provision or changes in the organization of activities. Companies with a low level of innovativeness predominated, i.e., introducing changes that are only new to the market itself or to the local market ( $41.8 \%$ of the sample tested). Enterprises introducing changes that are new on a national scale constituted $35.8 \%$ of the sample, while those introducing changes that are new on the international scale accounted for $22.4 \%$ of the sample. Compared to the entire population of 333 enterprises with a dominating share in local or national markets, the sample of 67 enterprises is characterised by a higher level of innovativeness, as the percentage of entities introducing new changes on a national or international scale in the population of 333 enterprises was $25.8 \%$, including $4.8 \%$ on the international scale, and was by 32.4 p.p. lower than in the group of 67 enterprises.

In the years 2014-2016, all the surveyed enterprises used business advisory services related to their business operations. The basic areas of services provided included sources of financing and accounting (39.3\% of enterprises), followed by legal and tax services (18.5\% of enterprises), manufacturing, logistics and IT (12.5\% of enterprises), as well as strategic and development management (10.5\% of enterprises) (Figure 1). Among the motives for using business advice, a gap in the business knowledge of managers, problems in company management and the development priorities of enterprises, were mentioned. As far as the scope of cooperation in the course of the advisory process is concerned, the examined sample is dominated by a lack of cooperation (32.8\% of entities) and partial cooperation regarding the implementation phase of business advice $(31.3 \%$ of companies). Partial cooperation (both in the phases of the initiative and implementation) concerns $46.2 \%$ of enterprises. Full cooperation of the company with the advisor (both during the initiative and implementation phase) was recorded by $20.9 \%$ of entities. Nearly $63 \%$ of enterprises using business advisory services stated that they obtained benefits as expected, and $34 \%$ of enterprises obtained benefits partly in line with expectations. Only $3 \%$ of entities claimed that the results of advisory services had not met their expectations. 


\section{RESULTS AND DISCUSSION}

\section{Determinants of competitiveness of enterprises excluding business advice}

The study of the competitiveness of enterprises operating in international markets concerned the estimation of business advantages that the enterprises had over the main market competitors in terms of resources, product or production characteristics such as novelty or innovativeness of the offer, costs or prices, quality, service, promotion, logistics, customer service, etc. The measurement of competitiveness was carried out on a 1-5 point scale, where 1 point meant very poor competitiveness and 5 points very strong competitiveness. The average level of competitiveness in the sample of enterprises was quite high and amounted to 3.4 points, while the median amounted to 3.0 points. $14.9 \%$ of enterprises were characterized by very weak or weak competitiveness, and $43.3 \%$ of enterprises by high or very high competitiveness.

The results of the analysis of the relationship between competitiveness and selected factors of functioning of the surveyed enterprises, mainly in the field of management, excluding business consulting, are presented in Table 1.

Table 1. Comparison of the relationship between the improvement in the competitiveness of enterprises and selected characteristics of enterprises excluding business consulting

\begin{tabular}{lll}
\hline Characteristics & Coefficient & Significance level \\
\hline Family relations among the board members & $0.411 \mathrm{a}$ & 0.034 \\
Business development priorities & $0.356 \mathrm{a}$ & 0.138 \\
Form of planning & $0.349 \mathrm{a}$ & 0.158 \\
Strategic management & $0.255 \mathrm{~b}$ & 0.037 \\
Business knowledge of managers & $0.249 \mathrm{~b}$ & 0.044 \\
Educational profile of managers & $0.401 \mathrm{a}$ & 0.172 \\
Number of people on the board & $0.267 \mathrm{a}$ & 0.526 \\
Age of enterprises & $0.201 \mathrm{~b}$ & 0.102 \\
Professional experience of managers & $0.191 \mathrm{~b}$ & 0.028 \\
Operational management & $0.183 \mathrm{~b}$ & 0.954 \\
Business knowledge absorptive capacity & $0.182 \mathrm{~b}$ & 0.163 \\
Scale of enterprises & $0.162 \mathrm{~b}$ & 0.189 \\
Innovations & $0.111 \mathrm{~b}$ & 0.373 \\
Industry & $0.102 \mathrm{a}$ & 0.002 \\
\hline
\end{tabular}

Note: a - measured by Pearson's C contingency coefficient; b - measured Spearman's rank correlation coefficient. 
The above-presented overview of factors indicates a limited range of competitiveness determinants in the sample - only 5 out of the list of 14 factors had a statistically significant impact on their competitiveness (at the 0.05 level of significance). It seems that these are mainly pro-development factors, positively affecting the competitiveness of enterprises. The role of innovation is irrelevant as a determinant of improving the competitiveness of the surveyed enterprises, however, it should be noted that companies with a high or very high level of innovativeness prevail in the sample.

\section{Determinants of competitiveness of enterprises including business advice}

The paper is an attempt to assess the moderating influence of business advice on improving the competitiveness of enterprises. The measurement was carried out on a 1-5 point scale, where 1 meant a very weak impact and 5 a very strong impact. The average level of impact of business advice on the improvement of competitiveness in the sample was moderate and amounted to 2.6 points, while the median amounted to 3.0 points. The results of the analysis of competitiveness determinants are presented in Table 2.

The survey indicates that the use of business advice extends the range of competitiveness determinants in the sample -11 out of the list of 14 factors (excluding business advice, i.e., advisory process, frequency of business advice, and business advice management) had a statistically significant impact on competitiveness (at the 0.05 level of significance). Only factors related to enterprises (industry, age and scale of enterprises) did not have a significant statistical impact on their competitiveness.

It is worth emphasising the great importance of the advisory process characteristics for assessing the impact of business advice on raising the level of enterprises' competitiveness. The greater the scope of advisory services, the higher the frequency of using business advice and the higher the level of management of advisory services, the higher the assessment of the importance of business advice in raising the level of competitiveness of enterprises.

The research also shows the positive impact of the current level of competitiveness of enterprises on the assessment of the importance of business advice for increasing the level of enterprises' competitiveness. This dependence is statistically significant, though moderate, and amounts to 0.250 with a significance level of 0.05 (measured by Spearman's rank correlation coefficient). It is fulfilled by a total of $2 / 3$ of the surveyed enterprises.

This means that the increase in the level of competitiveness is accompanied to a slightly greater extent by a higher assessment of the impact of business advisory services on the competitiveness of the surveyed enterprises than the reverse. 
Table 2. Comparison of the relationship between the improvement in the competitiveness of enterprises as a result of business advice and selected characteristics of enterprises

\begin{tabular}{lll}
\hline Characteristics & Coefficient & Significance level \\
\hline Advisory process & $0.645 \mathrm{a}$ & 0.000 \\
Educational profile of managers & $0.565 \mathrm{a}$ & 0.002 \\
Frequency of business advice & $0.544 \mathrm{a}$ & 0.000 \\
Business knowledge absorptive capacity & $0.517 \mathrm{~b}$ & 0.000 \\
Strategic management & $0.510 \mathrm{~b}$ & 0.000 \\
Operational management & $0.488 \mathrm{~b}$ & 0.000 \\
Business development priorities & $0.469 \mathrm{a}$ & 0.015 \\
Family relations among the board members & $0.465 \mathrm{a}$ & 0.018 \\
Form of planning & $0.452 \mathrm{a}$ & 0.028 \\
Number of people on the board & $0.434 \mathrm{a}$ & 0.049 \\
Professional experience of managers & $0.419 \mathrm{~b}$ & 0.000 \\
Business advice management & $0.405 \mathrm{~b}$ & 0.108 \\
Level of business knowledge of managers & $0.372 \mathrm{~b}$ & 0.002 \\
Innovations & $0.262 \mathrm{~b}$ & 0.032 \\
Industry & $0.364 \mathrm{a}$ & 0.598 \\
Age of enterprises & $0.069 \mathrm{~b}$ & 0.577 \\
Scale of enterprises & $0.067 \mathrm{~b}$ & 0.592 \\
\hline Note: $\mathrm{a}$-masuredby Pearson's Ccontingencycoefficient:b-measuredSpearman's rankcrrelationcoefficient
\end{tabular}

The low level of competitiveness is combined with a low assessment of the impact of business advice, as only $6.8 \%$ of enterprises in this group have increased their competitiveness thanks to advisory services. In the case of enterprises with a high level of competitiveness, the percentage was higher and amounted to $32.6 \%$.

Nearly $88 \%$ of enterprises characterized by a high assessment of the impact of business advice have increased their competitiveness, the remaining $12 \%$ of enterprises have not noticed any improvement in competitiveness due to personnel or resource constraints. In the case of enterprises with a low assessment of the impact of business advice on improving their competitiveness, $43.5 \%$ of these enterprises have managed to improve their competitiveness, which means that most of them did not have the potential to improve their competitiveness with a low share of the use of advisory services.

It can be assumed that generally, the surveyed enterprises have improved their competitiveness, which is accompanied by a high assessment of advisory services. In cases where enterprises determined the impact of business advice 
in improving their competitiveness as high, they were also the enterprises characterized by a high level of competitiveness. It seems, therefore, that a high level of competitiveness is conducive to the effectiveness of the use of business advice. Thus, if business advice can be considered as an effective factor in improving the competitiveness of enterprises, it concerns more highly competitive ones. Enterprises characterized by low competitiveness have improved their competitive position as a result of business advice to a significantly lesser degree.

Table 3. Basic differences in the characteristics of enterprises, including the impact of business advice on improving their competitiveness (\%)

\begin{tabular}{|c|c|c|}
\hline Characteristics & $\begin{array}{l}\text { Enterprises with } \\
\text { a low impact }\end{array}$ & $\begin{array}{l}\text { Enterprises with } \\
\text { a high impact }\end{array}$ \\
\hline Management experience (over 10 years) & $41.2 \%$ & $87.5 \%$ \\
\hline Level of business knowledge & Low (58.0\%) & High $(93.8 \%)$ \\
\hline Competitiveness & Low $(64.7 \%)$ & High (68.8\%) \\
\hline Business advice absorptive capacity & Low (54.6\%) & High (81.3\%) \\
\hline Scope of advisory process & $\begin{array}{l}\text { Implemented } \\
\text { together with the } \\
\text { advisor }(17.6 \%)\end{array}$ & $\begin{array}{l}\text { Implemented } \\
\text { together with the } \\
\text { advisor }(31.3 \%)\end{array}$ \\
\hline Level of business advice management & High (58.8\%) & High $(75 \%)$ \\
\hline
\end{tabular}

Data analysis confirms a large diversity of distinguished groups of enterprises in terms of the impact of business advice on the improvement of competitiveness which is dependent on: the professional experience of managers, the level of their business knowledge, the existing competitiveness of enterprises, their business advice absorptive capacity, the scope of the advisory process and the level of business advice management, i.e. obtaining greater benefits from business advice (Table 3 ).

\section{Business knowledge absorptive capacity and the competitiveness of enterprises including business advice}

In order to determine the impact of changes in business knowledge absorptive capacity, resulting from business advice, on the competitiveness of the surveyed enterprises, Spearman's rank correlation coefficient was applied. The analysis conducted shows that this relationship is statistically significant (Table 4). This applies to effects in all areas of absorption, with the exception of the ability to assimilate knowledge, for which such a relationship was turned out to be insignificant. As far as the individual areas of absorptive capacity are concerned, changes in absorptive capacity have the greatest 
impact on the competitiveness of enterprises in the case of their ability to transform knowledge (the coefficient was medium and amounted to 0.530), in other areas the coefficients are also medium (above 0.400). Otherwise, i.e., without using advisory services, this impact is weak and limited only to the area of the ability to absorb knowledge (the coefficient was at a level of 0.294 ) and to acquire knowledge (the coefficient was at a level of 0.260 ).

Table 4. Dependencies

\begin{tabular}{lll}
\hline Areas of business knowledge absorptive capacity & Coefficient & Significance level \\
\hline Excluding business advice & & \\
\hline Knowledge value recognition & 0.226 & 0.082 \\
Knowledge acquisition & 0.260 & 0.045 \\
Knowledge assimilation & 0.294 & 0.022 \\
Knowledge transformation & 0.116 & 0.379 \\
Knowledge exploitation & 0.065 & 0.623 \\
\hline Including business advice & & \\
\hline Knowledge value recognition & 0.426 & 0.001 \\
Knowledge acquisition & 0.470 & 0.000 \\
Knowledge assimilation & 0.105 & 0.424 \\
Knowledge transformation & 0.530 & 0.000 \\
Knowledge exploitation & 0.423 & 0.000 \\
\hline
\end{tabular}
Note: measured by Spearman's rank correlation coefficient.

The above-presented results seem to indicate that in the analyzed sample, the improvement in business knowledge absorptive capacity, as a result of business advice, was accompanied by an improvement in the competitiveness of the surveyed enterprises. On the other hand, a lack of business advice affected to a much lesser extent the relationship between business knowledge absorptive capacity and the improvement in the competitiveness of the surveyed enterprises.

\section{CONCLUSION}

The conducted analysis of the research results confirms the hypothesis concerning the correlation between management-related factors and the competitiveness of small innovative Polish enterprises operating in international markets. Management-related factors affecting strongly or moderately the competitiveness of the surveyed enterprises include family relations among the board members of enterprises and pro-development 
factors (business development priorities, form of planning, strategic management and the level of business knowledge of managers).

The survey indicates that the use of business advice extends the scope of determinants of the competitiveness of enterprises. The level of competitiveness is of crucial importance in assessing the role of business advice since advisory services can be considered as an effective factor in improving the competitiveness of enterprises characterized by high competitiveness, which means that a high level of competitiveness is conducive to the effectiveness of the use of advisory services. Enterprises characterized by low competitiveness have improved their competitive position as a result of business advice to a much lesser degree.

Among the characteristics that may affect the relationship between business advice and the competitiveness of enterprises are managementrelated factors. Relatively, the most favorable conditions for improving the competitiveness of enterprises as a result of the use of advisory services occurred in enterprises with more experienced managers characterized by greater professional experience; a higher level of business knowledge and a higher capacity for absorbing business knowledge; together with development orientation and a business plan; as well as a wider range of cooperation with advisors, and these are the enterprises that gained the greatest benefits from business advice. The results of the research confirm a large diversity of distinguished groups of enterprises in terms of the impact of business advice on the improvement of their competitiveness, which is dependent on: the professional experience of managers, the level of their business knowledge, the existing competitiveness of the enterprises, their business advice absorptive capacity, the scope of the advisory process and the level of business advice management, i.e. those that benefit to a greater extent from business advice.

In the sample of small, innovative enterprises, the improvement in their business knowledge absorptive capacity, as a result of business advice, was accompanied by an improvement in their competitiveness. To the highest degree, changes in absorptive capacity affected the competitiveness of the surveyed enterprises in the case of their ability to transform and acquire knowledge. On the other hand, a lack of business advice had an impact on the relationship between business knowledge absorptive capacity and the improvement in the competitiveness of the surveyed enterprises to a much lesser extent.

The paper has a number of limitations. It discusses specifically Polish conditions which are characterised by lower experience in the operation of small enterprises compared to the 'old countries' of the EU, mainly due to the relatively short period of development of the Polish SME sector (25- 
30 years) and the unsatisfactory state of business advice development, especially its mismatch to the needs of micro and small enterprises, as well as a lack of a tradition of cooperation between enterprises and commercial consultants (Stawasz \& Ropega 2014, pp. 99-113). The research is static and concerns results from one period. Moreover, only two-dimensional relations are considered. Estimation of the parameters of the econometric model could extend these analyses since the impact of a larger number of variables would be evaluated. This approach would result in obtaining a more complex framework for the analysis of the determinants of competitiveness. Future studies should be extended to include the economic performance of enterprises (revenues, costs). The role of entrepreneurship support policy may also require separate analysis as, in addition to the support for training, the support of the cooperation between small enterprises and advisors should also become an important element of this policy. Studies encompassing different periods, allowing for the comparison of changes in knowledge resources and interactions of managers with business advisors, would be interesting as well. Also of interest may be a comparative analysis of the role of business advice in managing small enterprises in countries with a different degree of development of this sector.

\section{References}

Adamik, A. (2011). Konkurencyjność i przewaga konkurencyjna MSP w teorii i praktyce. A. Adamik (Ed.), Kształtowanie Konkurencyjności i Przewagi Konkurencyjnej Małych i Średnich Przedsiębiorstw. Warszawa: Wydawnictwo C.H.Beck.

Ajmal, M. M., Nordstrom, F., \& Helo, P. (2009). Assessing the effectiveness of business consulting in operations development project. International Journal of Productivity and Performance Management, 58(6), 523-541. http://doi.org/10.1108/17410400910977073

Bennett, R.J. \& Robson, P. J. (2003). Changing use of external business advice and government support by SMEs in the 1990s. Regional Studies, 37(8), 795-811. http://doi.org/10.1080/0034340032000128721

Bianchi, C., Glavas, Ch., \& Mathews, Sh. (2017). SME international performance in Latin America: The role of entrepreneurial and technological capabilities. Journal of Small Business and Enterprise Development, 24(1), 176-195. http://doi.org/10.1108/JSBED-09-2016-0142

Blackburn, R. A., Hart, M., \& Wainwright, T. (2013). Small business performance: Business, strategy and owner-manager characteristics. Journal of Small Business and Enterprise Development. 20(1), 8-27. http://doi.org/10.1108/14626001311298394 
Caiazza, R., Richardson, A., \& Audretsch, D. (2015). Knowledge effects on competitiveness: From firms to regional advantage. Journal of Technology Transfer, 40(6), 899-909. http://doi.org/10.1007/s10961-015-9425-8

Carvalho, L., \& Costa, T. (2014). Small and medium enterprises (SMEs) and competitiveness - an empirical studies. Management Studies, 2(2), 88-95.

Chaston, I. (2010), Entrepreneurial Management Small Firms. London: SAGE Publications.

Chen, L-J., Chen, Ch-Ch., \& Lee, W-R. (2008). Strategic capabilities, innovation intensity, and performance of service firms. Journal of Service Science and Management, 1(2), 111-122.

Ciszewska-Mlinaric, M., Mlinaric, F., \& Obłój, K. (2011). Zdolność relacyjna, kompetencji organizacyjne i wyniki finansowe małych i średnich przedsiębiorstw słoweńskich. Master of Business Administration, 19(4), 23-35.

Delanoe, S. (2013). From intention to start-up: The effect of professional support. Journal of Small Business and Enterprise Development, 20(2), 383-398. http://doi.org/10.1108/14626001311326789.

Dobrea, M., \& Maiorescu, I. (2015). Entrepreneurial outcomes and organisational performance through business coaching. Amfiteatru Economic, 17(38), 247-260. http://hdl.handle.net/10419/168914

Dzikowska, M., \& Gorynia, M. (2012). Teoretyczne aspekty konkurencyjności przedsiębiorstwa - w kierunku koncepcji eklektycznej. Gospodarka Narodowa, 248(4), 1-30.

Freiling, J, Gersch, M., \& Goeke, C. (2008). On the path towards a competencebased theory of the firm. Organization Studies, 29(8-9), 1143-1164. http://doi.org/10.1177/0170840608094774.

Gooderham, P., Tobiassen, A. E., Doving, E., \& Nordhaug, O. (2004). Accountants as sources of business advice for small firms. International Small Business Journal, 22(1), 5-22.

Głodek, P., Łobacz, K., Stawasz, E., \& Niedzielski, P. (2016). Utilisation of business advice in small innovative firms - the role of trust and tacit knowledge. Entrepreneurial Business and Economics Review, 4(2), 117-138.

Grabowski, W., \& Stawasz, E. (2017). The role of business consulting in creating knowledge and formulating a strategy of development in Polish micro-enterprises. Journal for East European Management Studies, 22(3), 374-396.

Gudkova, S. (2008). Rozwój Małych Przedsiębiorstw. Warszawa: Wydawnictwa Akademickie i Profesjonalne.

Johnson, S., Webber, D.J., \& Thomas, W. (2007). Which SMEs use external business advice? A multivariate subregional study. Environment and Planning A, 39(8), 1981-1997. http://doi.org/10.1068/a38327

Kang, K. H., \& Kang, J. (2009). How do firms source external knowledge for innovation? Analysing effects of different knowledge sourcing methods. International Journal of Innovation Management, 13(1), 1-17. http:// doi.org/10.1142/S1363919609002194 
Karpacz, J. (2011). Determinanty Odnowy Strategicznej Potencjału Małych i Średnich Przedsiębiorstw. Warszawa: Oficyna SGH.

Liao, T-S., Rice, J., \& Lu, I-Ch. (2015). The vicissitudes of competitive advantage: Empirical evidence from Australian manufacturing SMEs. Journal of Small Business Management, 53(2), 469-481. http://doi.org/10.1111/jsbm.12078

Lisowska, R. (2015). External determinants of the development of small and medium-sized enterprises - empirical analysis. Journal of Entrepreneurship, Management and Innovation, 11(4), 115-138. https:// doi.org/10.7341/20151145

Łobacz, K., \& Głodek, P. (2015). Development of competitive advantage of small innovative firms - how to model business advice influence within the process? Procedia Economics and Finance, 23, 487-494. https://doi. org/10.1016/S2212-5671(15)00353-6

Malinowski, B. (2017). Metoda Oceny Wpływu Wybranych Innowacji Organizacyjnych na Biznesowq Pozycję Konkurencyjnq Małego Przedsiębiorstwa. Poznań: Wydawnictwo Politechniki Poznańskiej.

Man, T. W. Y., Lau, T., \& Snape, E. (2008). Entrepreneurial competencies and the performance of small and medium enterprises: An investigation through a framework of competitiveness. Journal of Small Business \& Entrepreneurship, 21(3), 257-276. https://doi.org/10.1080/08276331.2 008.10593424

Matejun, M. (2015). Absorpcja wsparcia w zarządzaniu rozwojem mikro, małych i średnich przedsiębiorstw - podejście strategiczne. Zeszyty Naukowe, 1194, Rozprawy Naukowe, 48. Łódź: Wydawnictwo Politechniki Łódzkiej.

Mole, K., North, D., \& Baldock, R. (2017). Which SMEs seek external support? Business characteristics, management behaviour and external influences in a contingency approach. Environment and Planning C: Politics and Space, 35(3), 476-499. https://doi.org/10.1177/0263774X16665362

Navarro, J. G. C., Eldridge, S., \& Wandosell, G (2016). International organizational performance: The influence of congenital learning and realized absorptive capacity. Journal of Small Business and Enterprise Development, 23(2), 453-473. https://doi.org/10.1108/ JSBED-05-2014-0078

North, D., Baldock, R., Mole, K., Wiseman, J., \& Binnie, C. (2011). Research to Understand the Barriers to Take up and Use of Business Support. London: For the Department for Business Innovation and Skills.

Patterson, W., \& Ambrosini, V. (2015). Configuring absorptive capacity as a key process for research intensive firms. Technovation, 36-37, 77-89. https://doi.org/10.1016/j.technovation.2014.10.003

Piatkowski, M. (2012). Factors strengthening the competitive position of SME sector enterprises. An example for Poland. Procedia - Social and Behavioral Sciences, 58, 269-278. https://doi.org/10.1016/j. sbspro.2012.09.1001

Plawgo, B. (2004). Zachowania Małych i Średnich Przedsiębiorstw w Procesie Internacjonalizacji. Warszawa: ORGMASZ. 
Ramsden, M., \& Bennett, R. J. (2005). The benefits of external support to SMEs: "Hard" versus "soft" outcomes and satisfaction levels. Journal of Small Business and Enterprise Development, 12(2), 227-243. https://doi. org/10.1108/14626000510594629

Robson, P. J. A., \& Bennett, R. J. (2000). The use and impact of business advice by SMEs in Britain: An empirical assessment using logit and ordered logit model. Applied Economics, 32(13), 1675-1688. https://doi. org/10.1080/000368400421020

Sciascia, S., D'Oria, L., Bruni, M., \& Larraneta, B. (2014). Entrepreneurial orientation in low- and medium-tech industries: The need for absorptive capacity to increase performance. European Management Journal, 32(5), 761-769. https://doi.org/10.1016/j.emj.2013.12.007

Sipa, M., Gorzeń-Mitka, I., \& Skibiński, A. (2015). Determinants of competitiveness of small enterprises: Polish perspective. Procedia Economics and Finance, 27, 445-453. https://doi.org/10.1016/S22125671(15)01019-9.

Soriano, D. R., \& Castrogiovanni, G. J. (2012). The impact of education, experience and inner circle advisors on SME performance: Insights from a study of public development centers. Small Bussiness Economics, 38(3), 333-349. https://doi.org/10.1007/s11187-010-9278-3

Stanisławski, R. (2013). Wpływ dynamicznych zdolności innowacyjnych na kształtowanie przewagi konkurencyjnej małych i średnich przedsiębiorstw w Polsce. Organizacja i Kierowanie, 4(157), 119-139.

Stankiewicz, M. J. (2002). Konkurencyjność Przedsiębiorstwa. Budowanie Konkurencyjności Przedsiębiorstwa w Warunkach Globalizacji. Toruń: Dom Organizatora.

Stawasz, E., \& Ropega, J. (2014). Barriers and risk factors in the development of micro and small businesses in Poland. In A. S. Gubik \& K. Wach (Eds.), International Entrepreneurship and Corporate Growth in Visegrad Countries (pp. 99-113). Miscolc: University of Miscolc.

Stawasz, E. (2013). Innowacje a konkurencyjność małych przedsiębiorstw. Organizacja i Zarzqdzanie. Zeszyty Naukowe, 53, 17-28.

Stoian, M. C., Rialp, A., Rialp, J., \& Jarvis, R. (2016). Internationalisation of central and eastern european small firms: Institutions, resources and networks. Journal of Small Business and Enterprise Development, 23(1), 105-121. https://doi.org/10.1108/JSBED-10-2013-0159

Supyuenyong, V., Islam, N., \& Kulkarni, U. (2009). Influence of SME characteristics on knowledge management processes: The case study of enterprise resource planning service providers. Journal of Enterprise Information Management, 22(1), 63-143. https://doi. org//10.1108/17410390910922831

Todorova, G., \& Durisin, B. (2007). Absorptive capacity: Valuing a reconceptualization. Academy of Management Review, 32(3), 774-786. https://doi.org/10.2307/20159334 
Wach, K. (2017). Orientacja przedsiębiorcza a wiedza w początkowym i dojrzałym etapie procesu internacjonalizacji przedsiębiorstw. Studia Ekonomiczne. Zeszyty Naukowe Uniwersytetu Ekonomicznego w Katowicach, 319, 268-282.

Wiklund, J., \& Shepherd, D. (2003). Knowledge-based resources, entrepreneurial orientation, and the performance of small and mediumsized businesses. Strategic Management Journal, 24(13), 1307-1314. https://doi.org/10. IOO2/smj.360

Volberda, H. W., Foss, N.J., \& Lyles, M. A. (2010). Absorbingthe concept of absorbing capacity: How to realize its potential in the organization field. Organization Science, 21(4), 931-951. https://doi.org/10.1287/orsc.1090.0503

Zahra, S. A., \& George, G. (2002). Absorptive capacity: A review, reconceptualization, and extension. Academy of Management Review, 27(2), 185-203. https://doi.org/10.5465/AMR.2002.6587995

Zvirblis, A., \& Buracas, A. (2012). Backgrounds of aggregated assessment of SMEs competitive advantage determinants. TEM Journal, 1(4), 213-220.

Yusoff, N. H., Yaacob, R., \& Ibrahim, D. (2010). Business advisory: A study on selected micro-sized SMEs in Kelantan, Malaysia. International Journal of Marketing Studies, 2(2), 245-257. https://doi.org/10.5539/ijms.v2n2p245

\begin{abstract}
Abstrakt
Celem prezentowanego artykułu jest identyfikacja znaczenia wybranych determinantów konkurencyjności małych przedsiębiorstw innowacyjnych działajqcych na rynkach międzynarodowych, korzystajqcych z doradztwa biznesowego. Osiagnięcie tego celu wymagało: określenia determinantów konkurencyjności małych przedsiębiorstw (charakterystyki zarzqdzajqcych, charakterystyki przedsiębiorstw), omówienia motywów, obszarów oraz efektów korzystania z doradztwa biznesowego. Przedstawiono także zagadnienie zdolności absorpcji wiedzy biznesowej jako determinanty konkurencyjności małych przedsiębiorstw oraz warunku skuteczności korzystania z zewnętrznej wiedzy biznesowej. W drugiej części artykułu przedstawiono wyniki badań empirycznych przeprowadzonych w 2016 r. technikq CATI na próbie 67 matych polskich przedsiębiorstw innowacyjnych działajacych na rynkach międzynarodowych i równocześnie korzystajqucych z doradztwa biznesowego. Przeprowadzone badania potwierdzajq hipotezę o istotnym modyfikujacym wpływie doradztwa biznesowego na układ determinant konkurencyjności przedsiębiorstw. Potwierdzona została także hipoteza o pozytywnym zwiqzku doradztwa biznesowego i zdolności absorpcji wiedzy biznesowej przedsiębiorstw, a pośrednio na ich konkurencyjność. Poprawa konkurencyjności przedsiębiorstw wymaga korzystania z doradztwa biznesowego i poprawy zdolności absorpcji wiedzy biznesowej.
\end{abstract}

Słowa kluczowe: mały biznes, determinanty konkurencyjności na rynkach międzynarodowych, doradztwo biznesowe, zdolność absorpcji wiedzy biznesowej. 


\section{Biographical note}

Edward Stawasz, Ph.D. Habilitated, Associate Professor at the Department of Entrepreneurship and Industrial Policy, Faculty of Management, University of Lodz, Poland, head of the Department. His research, publication and consulting activities focus on entrepreneurship and business management, innovation management, technology management and commercialization, and business advice for SMEs. He has many years' experience as the head, and a participant, of research projects and he is the author and a co-author of about 150 publications in the field of SMEs' management and innovation management. 